\title{
Top-dressing $1 \%$ arginine supplementation in the lactation diet of sows does not affect the litter performance and milk composition
}

\author{
A suplementação de $1 \%$ de arginina via top-dress na dieta de lactação de porcas não afeta o \\ desempenho das leitegadas e a composição do leite
}

\author{
Djane Dallanora, II Marina Patricia Walter ${ }^{\text {II }}$ Jéssica Marcon ${ }^{\text {II }}$ Camila Saremba ${ }^{\text {II }}$ \\ Mari Lourdes Bernardi ${ }^{\mathrm{III}}$ Ivo Wentz $^{\mathrm{IV}}$ Fernando Pandolfo Bortolozzo ${ }^{\mathrm{IV}}$
}

\section{ABSTRACT}

The study aimed to evaluate the effects of arginine supplementation in the lactation diet of sows on their milk composition, litter performance and piglet survival. Sixty-four lactating Landrace $x$ Large White sows, parity 1 to 7 , were randomly assigned to two treatments: 1) Control - a corn/soybean meal based diet with $1.10 \%$ standardized ileal digestible (SID) lysine and $3,475 \mathrm{kcal}$ of metabolizable energy (ME) $\mathrm{kg}^{-1}$, and 2) arginine - the control diet top-dressed daily with arginine at $1 \%$ of feed allowance. The daily feed allowance per sow was 5.0 and $7.5 \mathrm{~kg}$ from day (D) 0 to D7 and D8 to D21, respectively. The average litter size was 12.8 piglets after cross-fostering. Litters were weighed on D1, D10, and D21 of lactation and pre-weaning mortality was recorded. Samples of milk $(60 \mathrm{~mL})$ were collected from all functional teats at D10 and D20 of lactation. There were no effects $(P>0.05)$ of arginine supplementation on piglet weight, litter weight, and average daily gain of piglets at D10 and D21 of lactation. The interaction between weight day and treatment was not significant $(P>0.05)$ for any of these response variables. The percentages of piglets that survived until D10 and D21 were $90.3 \%$ and $88.3 \%$, respectively, with no difference $(P>0.05)$ between treatments. There were no effects $(P>0.05)$ of the lactation day (D10 or D20), treatment or the interaction between them on crude protein and amino acid content in milk. Top-dressing arginine at $1 \%$ of feed allowance of the lactation diet of sows does not affect litter performance and survival and does not influence the amino acid content or arginine: lysine ratio of milk.

Key words: amino acids, piglets, weight gain.

RESUMO

$O$ estudo teve o objetivo de avaliar o efeito da suplementação de arginina na dieta de lactação de porcas sobre a composição do leite, desempenho da leitegada e sobrevivencia dos leitões. Foram utilizadas 64 porcas lactantes Landrace - Large White, com parição de 1 a 7, aleatoriamente distribuidas em dois tratamentos: 1) Controle - dieta a base de milho e soja com 1,10\% de lisina digestivel e $3.475 \mathrm{kcal}$ de energia metabolizável; e 2) Arginina - dieta controle suplementada com arginina via top-dress em nivel de 1\% sobre a dieta fornecida. Diariamente, as matrizes receberam 5,0 e 7,5kg do D0 ao D7 e D8 ao D21, respectivamente. Após a uniformização das leitegadas, o número médio de lactentes foi de 12,8 leitões. As leitegadas foram pesadas no D1, D10 e D21 da lactação e a mortalidade pré-desmame foi registrada. Foram coletadas amostras de leite $(60 \mathrm{~mL})$ de todas as tetas funcionais de cada porca no D10 e no D20 da lactação. Não houve efeito $(P>0,05)$ da suplementação de arginina sobre o peso dos leitões, peso da leitegada e ganho de peso médio diário dos leitões no D10 e D21 da lactação. A interação entre dia da pesagem e tratamento não foi significativa $(P>0,05)$ para as variáveis-resposta analisadas. Os percentuais de leitões vivos até o D10 e D21 foram de $90,3 \%$ e $88,3 \%$, respectivamente, sem diferença $(P>0,05)$ entre os tratamentos. Não houve efeito $(P>0,05)$ do dia de lactação $(D 10$ ou D20), tratamento ou interação entre eles na proteina bruta e conteúdo de aminoácidos do leite. A suplementação de arginina em nível de $1 \%$ da dieta fornecida diariamente não teve efeito sobre o desempenho e sobrevivência da leitegada e não influenciou no conteúdo de aminoácidos ou na relação arginina:lisina do leite.

Palavras-chave: aminoácidos, leitões, ganho de peso.

\section{INTRODUCTION}

The potential for milk production of sows increased nearly four times from 1930 to 2010; a ratio

\footnotetext{
IPrograma de Pós-graduação em Ciências Veterinárias (PPGCV), Universidade Federal do Rio Grande do Sul (UFRGS), Porto Alegre, RS, Brasil.

IFaculdade de Medicina Veterinária, Universidade do Oeste de Santa Catarina (UNOESC), Xanxerê, SC, Brasil.

IIIDepartamento de Zootecnia, Faculdade de Agronomia, Universidade Federal do Rio Grande do Sul (UFRGS), Porto Alegre, RS, Brasil.

${ }^{\text {IV }}$ Setor de Suínos, Departamento de Medicina Animal, Faculdade de Veterinária, Universidade Federal do Rio Grande do Sul (UFRGS),

Av. Bento Gonçalves, 9090, 91540-000, Porto Alegre, RS, Brasil. E-mail: fpbortol@ufrgs.br. "Corresponding author.
} 
of $60 \mathrm{~g}$ of milk produced $/ \mathrm{kg}$ live weight is currently estimated (KIM et al., 2013). In the last decade, research efforts have been directed toward reviewing the nutritional requirements of sows from modern genetic lines at various levels: in the energy and amino acid content of diets, ratios of other amino acids to lysine according to the stage of production, as well as the individual supplementation of some amino acids via top-dressing (KIM et al., 2004; MATEO et al., 2008; YANG et al., 2008).

Among the amino acids, arginine has been studied due to its importance in milk production and the development of suckling piglets (WU \& MORRIS, 1998; KIM et al., 2004; MATEO et al., 2008; LIMA, 2010). Arginine stimulates the secretion of prolactin and growth hormone (REYES et al., 1994) and participates in angiogenesis in mammary tissue (MATEO et al., 2008). Due to the effects of arginine on nitric oxide production and vasodilation, this amino acid causes an increase in local blood flow, resulting in higher nutrient supply which could increase milk production (TROTTIER et al., 1997; WU \& MEININGER, 2000). Furthermore, the possibility of changing the content of arginine in colostrum and milk could reduce the deficit of this amino acid in newborn piglets (WU et al., 2004; KIM et al., 2007). WU et al. (2000) estimated that sow milk supplies less than $40 \%$ of the arginine requirement of a 7-day old piglet. Therefore, alternative approaches to supplement this amino acid could be very useful to improve performance in this phase (KIM et al., 2004). Recently, the possibility of increasing the arginine content of the milk by top-dressing in lactating sows diets has been explored (MATEO et al., 2008; LIMA, 2010); this strategy could be readily applied on commercial pig farms. The objective of this study was to evaluate the effects of arginine supplementation in the lactation diet of hyper-prolific modern genotype sows on their milk composition, litter performance and survival of suckling piglets.

\section{MATERIALS AND METHODS}

The experiment was conducted in a commercial pig farm in the Midwest region of Brazil. A total of 64 lactating sows (Landrace $\mathrm{x}$ Large White), parity 1 to 7 , were used in this experiment. After cross-fostering, on the first day (D) after farrowing (D1), sows were randomly assigned to two treatments in a completely randomized design: 1) control - corn/soybean meal based diet with $1.10 \%$ standardized ileal digestible (SID) lysine and $3,475 \mathrm{kcal}$ of metabolizable energy (ME) $\mathrm{kg}^{-1}$, and 2) arginine - the control diet top-dressed daily with arginine at $1 \%$ of feed allowance. The daily individual feed allowance was $5.0 \mathrm{~kg}$ of lactation diet during the first week of lactation (D1-D7) and followed by $7.5 \mathrm{~kg}$ of the same diet until weaning (D8-D21), in two and three meals/day/sow, respectively. The diet was served using the automatic system and the amount offered was confirmed by individual weighing once a week. Therefore, sows assigned to the arginine treatment were fed with 50 and $75 \mathrm{~g} \mathrm{~d}^{-1}$ of L-arginine $\mathrm{HCl}$ (Aminoscience Division - Ajinomoto do Brasil Indústria e Comércio de Alimentos Ltda, Limeira, São Paulo, Brazil) from D0 to D7 and D8 to D21, respectively. The amount of supplemental arginine was weighed for each sow, on a digital balance ( $1 \mathrm{~g}$ of precision), and served throughout lactation, once a day in the morning, poured directly onto the feed in the individual feed drop of the sow. There were no leftovers of feed and sows had ad libitum access to water throughout the experiment. Distribution of sows among the treatments was conducted in order to have a similar litter size $(12.8 \pm 1.2$ piglets $)$, average initial litter weight $(20.7 \pm 3.7 \mathrm{~kg})$, and sow parity (4.0 \pm 1.8 parities). All sows were fed with a control diet (Table 1), which met the requirements suggested by ROSTAGNO et al. (2011) and NRC (2012). Litters were weighed on D1, D10, and D21 of lactation and pre-weaning mortality was recorded for the calculation of piglet survival on D10 and D21.

Milk composition was evaluated by collecting $60 \mathrm{~mL}$ samples of milk from 18 sows per treatment on D10 and D20 of lactation. Milk sampling was performed by hand milking all functional teats after intramuscular injection of $2 \mathrm{~mL}$ of carbetocin (Hertape Calier Animal Health S.A., Juatuba, MG, Brazil). Milk samples were kept frozen at $-20^{\circ} \mathrm{C}$ and submitted for analysis (Ajinomoto's Aminoscience Division, Limeira, São Paulo, Brazil). The amino acid composition of the milk was determined by high efficiency liquid chromatography, as described in the COMPÊNDIO BRASILEIRO DE ALIMENTAÇÃO ANIMAL (2009).

All statistical analyses were performed using the Statistical Analysis System (SAS) software, version 9.2 (2005, SAS Institute Inc., Cary, NC, USA). Results were considered significant at $\mathrm{P} \leq 0.05$. All data were tested for normality with the Shapiro-Wilk test. For all the measurements concerning the piglets, the litter was considered as the experimental unit. Milk composition, average piglet weight, litter weight, 
Table 1 - Composition of the control diet (as-fed basis).

\begin{tabular}{|c|c|}
\hline Item & Control \\
\hline \multicolumn{2}{|c|}{ - } \\
\hline Corn & 516.15 \\
\hline Soybean meal & 325.00 \\
\hline Sugar & 40.00 \\
\hline Dicalcium phosphate & 15.00 \\
\hline Soybean oil & 51.00 \\
\hline Sodium bicarbonate & 2.50 \\
\hline Vitamin premix ${ }^{1}$ & 0.40 \\
\hline Trace mineral premix ${ }^{2}$ & 1.00 \\
\hline L-lysine & 2.00 \\
\hline DL- methionine & 2.18 \\
\hline L-threonine & 2.29 \\
\hline Others & 42.7 \\
\hline Total & 1,000 \\
\hline \multicolumn{2}{|c|}{--------Standardized ileal digestible (SID) amino acids, \%-------- } \\
\hline Lysine & 1.10 \\
\hline Methionine \& cysteine:lysine & 70 \\
\hline Threonine:lysine & 80 \\
\hline Tryptophan:lysine & 19 \\
\hline Arginine:lysine & 109 \\
\hline Dry matter, \% & 89.52 \\
\hline ME, kcal kg ${ }^{-1}$ & 3,475 \\
\hline $\mathrm{CP}, \%$ & 19.31 \\
\hline $\mathrm{Ca}, \%$ & 0.95 \\
\hline $\mathrm{P}, \%$ & 0.50 \\
\hline
\end{tabular}

${ }^{1}$ Provided per $\mathrm{g}$ of vitamin premix: $12 \mathrm{IU}$ vitamin $\mathrm{A} ; 2,400 \mathrm{IU}$ vitamin D3; 0.08IU vitamin E; 2,680ppm vitamin $\mathrm{K} 3 ; 2,00 \mathrm{ppm}$ vitamin $\mathrm{B} 1 ; 4,4 \mathrm{ppm}$ riboflavin; 2,4ppm pyridoxine; $26,8 \mathrm{ppb}$ vitamin B12; 26,8ppm niacin; 12,0ppm pantothenic acid; $1,680 \mathrm{ppm}$ folic acid; $0.00097 \mathrm{mg}$ biotin; $1,800 \mathrm{ppm}$ choline

${ }^{2}$ Provided per g of trace mineral premix: $0.30 \mathrm{ppm}$ Se from sodium selenite; 113ppm Fe from iron sulfate; 50ppm $\mathrm{Cu}$ from copper sulfate; 42ppm Mn from manganese oxide; 132ppm Zn from zinc oxide; $1.26 \mathrm{ppm}$ I from ethylenediamine dihydroiodide; 28,125ppm; $0.5 \mathrm{ppm}$.

and average daily gain (ADG) were analyzed as a completely randomized design with repeated measures using the MIXED procedure. For milk composition analysis, the model included the fixed effect of treatments and sows were used as a random effect. Models for litter weight, average piglet weight and ADG included fixed effect of treatments and random effect of sow parity as well as the litter weight at D1 and the number of suckling piglets as covariates. Piglet survival was analyzed by fitting a non-parametric model using the NPAR1WAY procedure and the Wilcoxon test because it did not follow a normal distribution.

\section{RESULTS}

There were no effects of day of lactation (D10 and D20), treatments or the interaction between them on the crude protein and amino acid content in milk (Table 2, $\mathrm{P}>0.05$ ). Overall, the arginine: lysine ratio in milk was 60:100, and no difference $(\mathrm{P}>0.05)$ between treatments was observed. There were no effects of arginine supplementation on average piglet weight, litter weight, or ADG either on D10 or D21 (Table 3, P $>0.05$ ). The interaction between the weighing day and treatment was not significant $(\mathrm{P}>0.05)$ for any of these variables. Piglet ADG was $0.216,0.207$, and 0.212 for the periods D1-D10, D11-D21, and D1-D21, respectively. Piglet survival on D10 and D21 was not different $(\mathrm{P}>0.05)$ between the control and arginine treatments (Table 3).

\section{DISCUSSION}

Since arginine is an essential amino acid for young piglets (O'QUINN et al., 2002) and its supplementation in artificially fed neonates improved their development (KIM et al., 2004), it has been speculated about the potential ability to manipulate milk composition with arginine supplementation. TROTTIER et al. (1997) observed that the level of arginine in sow's milk is smaller than the supply of this amino acid to the mammary gland due to its continue degradation by mammary tissue (O'QUINN et al., 2002). In the present study, crude protein or amino acid content of milk, including arginine itself, were not altered by topdressing L-arginine HCL at $1 \%$ supplementation, indicating that despite increasing arginine supply in the bloodstream, level of supplementation was not enough to exceed the threshold of arginine degradation in the mammary tissue.

The performance of piglets during lactation is highly correlated with sow's milk production and the nutrient concentration in milk (NOBLET \& ETIENNE, 1987; KIM et al., 1999). Similar ADG of piglets between treatments indicates that arginine did not increase milk production. If the second half of lactation (D11-D21) is taken into account, the lack of effects of arginine supplementation on ADG of piglets corroborates the results of other studies (MATEO et al., 2008; LIMA, 2010). The study conducted by MATEO et al. (2008) was the only one in which an arginine-supplemented diet increased the ADG of piglets between D0 and D21. The discrepancy with the results of our study may be associated with the fact that arginine was mixed in the diet at the feed mill and 
Table 2 - Influence of top-dressing arginine in lactation diets on milk composition of the sow ${ }^{1,2}$.

\begin{tabular}{|c|c|c|c|c|}
\hline \multirow{2}{*}{ Item } & \multicolumn{2}{|c|}{-----------------------D10----------------------' } & \multicolumn{2}{|c|}{-----------------------D20--------------------- } \\
\hline & Control & Arginine & Control & Arginine \\
\hline Crude Protein, $\%$ & $5.247 \pm 0.126$ & $5.251 \pm 0.119$ & $5.491 \pm 0.119$ & $5.321 \pm 0.113$ \\
\hline \multicolumn{5}{|l|}{-------------------- } \\
\hline Lysine & $0.407 \pm 0.011$ & $0.405 \pm 0.013$ & $0.404 \pm 0.011$ & $0.421 \pm 0.010$ \\
\hline Threonine & $0.229 \pm 0.005$ & $0.225 \pm 0.005$ & $0.225 \pm 0.005$ & $0.232 \pm 0.005$ \\
\hline Methionine & $0.104 \pm 0.003$ & $0.103 \pm 0.002$ & $0.106 \pm 0.003$ & $0.106 \pm 0.003$ \\
\hline Cysteine & $0.070 \pm 0.070$ & $0.071 \pm 0.071$ & $0.070 \pm 0.071$ & $0.069 \pm 0.071$ \\
\hline Methionine\&Cysteine & $0.175 \pm 0.004$ & $0.173 \pm 0.004$ & $0.176 \pm 0.004$ & $0.175 \pm 0.004$ \\
\hline Alanine & $0.207 \pm 0.008$ & $0.201 \pm 0.008$ & $0.198 \pm 0.007$ & $0.205 \pm 0.007$ \\
\hline Arginine & $0.245 \pm 0.007$ & $0.240 \pm 0.007$ & $0.245 \pm 0.006$ & $0.247 \pm 0.006$ \\
\hline Aspartic acid & $0.443 \pm 0.012$ & $0.437 \pm 0.011$ & $0.433 \pm 0.011$ & $0.446 \pm 0.010$ \\
\hline Glutamic acid & $1.113 \pm 0.029$ & $1.088 \pm 0.027$ & $1.127 \pm 0.028$ & $1.146 \pm 0.027$ \\
\hline Glycine & $0.171 \pm 0.005$ & $0.166 \pm 0.005$ & $0.169 \pm 0.004$ & $0.170 \pm 0.004$ \\
\hline Histidine & $0.142 \pm 0.003$ & $0.146 \pm 0.003$ & $0.147 \pm 0.004$ & $0.149 \pm 0.003$ \\
\hline Isoleucine & $0.214 \pm 0.005$ & $0.209 \pm 0.005$ & $0.211 \pm 0.005$ & $0.219 \pm 0.005$ \\
\hline Leucine & $0.471 \pm 0.010$ & $0.458 \pm 0.010$ & $0.468 \pm 0.009$ & $0.471 \pm 0.008$ \\
\hline Phenylalanine & $0.224 \pm 0.005$ & $0.217 \pm 0.005$ & $0.225 \pm 0.005$ & $0.228 \pm 0.005$ \\
\hline Serine & $0.280 \pm 0.008$ & $0.274 \pm 0.007$ & $0.277 \pm 0.007$ & $0.285 \pm 0.006$ \\
\hline Tyrosine & $0.223 \pm 0.006$ & $0.215 \pm 0.005$ & $0.220 \pm 0.004$ & $0.226 \pm 0.004$ \\
\hline Valine & $0.277 \pm 0.007$ & $0.274 \pm 0.006$ & $0.275 \pm 0.006$ & $0.283 \pm 0.006$ \\
\hline
\end{tabular}

${ }^{1}$ Effects of treatment, day of milk collection or their interaction were not significant $(\mathrm{P}>0.05)$.

${ }^{2}$ Results are reported as mean \pm SEM, where SEM stands for standard error of the mean.

only primiparous sows were used by MATEO et al. (2008). It is important to highlight that LIMA (2010) used multiparous sows and did not show any effects of arginine on ADG of piglets. Due to the higher feed intake (ABREU et al., 2013) of multiparous sows, which represented about $90 \%$ of the sows evaluated in the present study, it is likely that their requirement for arginine may have already been met and topdressed arginine was unnecessary.

Apparently, there was a limitation in the potential growth of piglets in the second half of lactation, in the present study, since piglet ADG was similar between the first and second half of lactation, contrasting with reports of an increase in ADG as piglets got older (MATEO et al., 2008; LIMA, 2010). As sows did not present any clinical signs suggestive of disease, one can speculate that the control diet as well as the arginine diet did not promote enough milk production to maximize piglet weight gain in the second half of lactation, when the peak of milk production occurs.

There were no effects of arginine supplementation on piglet survival which disagrees with LIMA (2010), who observed an average survival of $82 \%$ in the group supplemented with $1 \%$ arginine and $75 \%$ in the control group. The greater litter weight observed by LIMA (2010) was probably the result of increased piglet survival, since piglet ADG from D1-D21 was not increased by arginine supplementation. Although pre-weaning mortality reasons were not recorded, LIMA (2010) suggested that supplementation with $1 \%$ arginine resulted in increased milk production in the first week of lactation, which could have reduced disputes among littermates (14 piglets after cross-fostering). In pigs, milk production can be influenced by either insufficiency or excess of energy and protein in the diet (KIM et al., 1999, ABREU et al., 2013). When amino acids are supplemented, there must be a concern with the possibility of ammonia poisoning, which causes alterations in metabolism and undesirable effects on blood flow to the mammary gland, thus reducing milk production and performance of piglets (WU et al., 2013). According to WU \& MORRIS (1998), under normal feeding conditions, the arginine: lysine ratio cannot be higher than 150:100, because these amino acids compete for intracellular transport. WU et al. (2013) recommend that the total arginine content of the diet should be less than $2 \%$ (based on a diet with $90 \%$ dry matter) and that the 
Table 3 - Influence of top-dressing arginine in lactation diets on litter performance and survival.

\begin{tabular}{|c|c|c|c|c|}
\hline Item & Control & Arginine & \multirow[t]{2}{*}{$\mathrm{SEM}^{1}$} & \multirow[t]{2}{*}{ Probability } \\
\hline Sows per treatment, $\mathrm{n}$ & 32 & 32 & & \\
\hline \multicolumn{5}{|l|}{------------------------------- } \\
\hline D1 & 21.15 & 20.27 & 0.662 & 0.351 \\
\hline D10 & 40.75 & 41.07 & 2.240 & 0.818 \\
\hline D21 & 66.94 & 67.00 & 2.866 & 0.983 \\
\hline \multicolumn{5}{|l|}{------ } \\
\hline D10 & 3.57 & 3.56 & 0.174 & 0.884 \\
\hline $\mathrm{D} 21$ & 5.83 & 5.83 & 0.218 & 0.989 \\
\hline \multicolumn{5}{|c|}{ 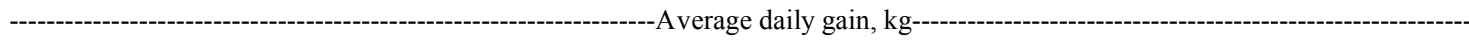 } \\
\hline D1-D10 & 0.219 & 0.216 & 0.021 & 0.811 \\
\hline D11-D21 & 0.207 & 0.207 & 0.022 & 0.990 \\
\hline D1-D21 & 0.213 & 0.211 & 0.019 & 0.844 \\
\hline \multicolumn{5}{|c|}{ - } \\
\hline D10 & $89.7(71.4 ; 92.6 ; 100)$ & $90.9(70.0 ; 92.3 ; 100)$ & 1.159 & 0.940 \\
\hline D21 & $87.8(70.0 ; 92.0 ; 100)$ & $88.8(69.2 ; 92.0 ; 100)$ & 1.267 & 0.989 \\
\hline
\end{tabular}

${ }^{1}$ SEM: standard error of the mean.

${ }^{2}$ In parentheses: minimum, median, and maximum.

SID arginine:lysine ratio should be less than 3.0\%. Similarly, EDMONDS et al. (1987) considered safe the use of arginine supplementation up to $2.5 \%$ of dry matter for pigs. Assuming $89 \%$ dry matter in the basal diet used in the present study, $2.5 \%$ of dry matter would be $168 \mathrm{~g}$ SID arginine $\mathrm{d}^{-1}$. However, no more than $75 \mathrm{~g} \mathrm{~d}^{-1}$ of L-arginine $\mathrm{HCl}$ were supplemented in the arginine treatment, therefore, not reaching the suggested upper limit.

Top-dressing can be used as an approach for the adoption of practices like phase feeding during gestation or parity segregated feeding regimen, fine tuning the feeding program (KIM et al., 2009) to meet the wide variety of nutrient requirements within the breeding herd. As mentioned, in the present study, arginine was top-dressed once a day in the individual feed reservoir of the sow. Since arginine has a short plasma half-life (WU et al., 2007), it may have been inefficiently used, because synthetic amino acids added in a single meal are absorbed more quickly than those from intact protein, and can be oxidized rapidly (YEN et al., 2004). The addition of arginine to the diet in the feed mill, as performed in other studies (MATEO et al., 2008; LIMA, 2010), is a more efficient alternative than top-dressing.

\section{CONCLUSION}

Top-dressing L-arginine $\mathrm{HCL}$ at $1 \%$ of the feed allowance of primiparous and multiparous lactating sows does not influence milk composition, litter performance, or survival of suckling piglets.

\section{ACKNOWLEDGMENTS}

The authors thank the Aminoscience Division Ajinomoto do Brasil Indústria e Comércio de Alimentos Ltda for the donation of arginine and Dr. Rubens Valentini, owner of Miunça Farm, for their assistance in this work.

\section{REFERENCES}

ABREU, M.L.T et al. Atualizando a nutrição de porcas hiperprolíficas. In: SIMPÓSIO BRASIL SUL DE SUINOCULTURA, 4., 2013, Chapecó, SC. Anais... Chapecó/ SC: Núcleo Oeste de Médicos Veterinários, 2013. p.70-92.

COMPÊNDIO BRASILEIRO DE ALIMENTAÇÃO ANIMAL, Sindirações. São Paulo, 2009. p.48-64.

EDMONDS, M.S. et al. Effect of excess levels of methionine, tryptophan, arginine, lysine or threonine on growth and dietary choice in the pig. Journal of Animal Science, v.65, n.1, p.179185, 1987. Available from: <http://www.journalofanimalscience. org/content/65/1/179.full.pdf>. Accessed: May 5, 2010.

KIM, S.W. et al. Effect of nutrient intake on mammary gland growth in lactating sows. Journal of Animal Science, v.77, p.33043315, 1999. Available from: $<$ http://www.journalofanimalscience. org/content/77/9/251>. Accessed: Mar. 27, 2011.

KIM, S.W. et al. Dietary arginine supplementation enhances the growth of milk fed young pigs. Journal of Nutrition, v.134, p.625-630, 2004. Available from: <http://jn.nutrition. org/content/134/3/625.full.pdf>. Accessed: Feb. 23, 2013. doi: 10.1007/s00726-011-0960-9. 
KIM, S.W. et al. Functional amino acids and fatty acids for enhancing production performance of sows and piglets. AsianAustralian Journal of Animal Science, v.20, n.2, p.295-306, 2007. Available from: <http://ajas.info/upload/pdf/20-40.pdf >. Accessed: May 5, 2010.

KIM, S.W. et al. Ideal amino acid balance for sows during gestation and lactation. Journal of Animal Science, v.87, p.123-132, 2009. Available from: <http:/www.animalsciencepublications.org/ publications/jas/pdfs/87/14_suppl/0870123>. Accessed: Oct. 15, 2010

KIM, S.W. et al. Improving efficiency of sow productivity: nutrition and health. Journal of Animal Science and Biotechnology, v.4:26, p.1-8, 2013. Available from: <http://www.jasbsci.com/ content/pdf/2049-1891-4-26.pdf $>$. Accessed: Feb. 5, 2014. doi: $10.1186 / 2049-1891-4-26$.

LIMA, D. de. Dietas suplementadas com arginina para fêmeas suínas hiperprolíferas no período final da gestação e na lactação. 2010. 61f. Dissertação (Mestrado Ciências Veterinárias) - Programa de Pósgraduação em Ciências Veterinárias, Universidade Federal de Lavras, MG.

MATEO, R.D. et al. Effects of dietary arginine supplementation during gestation and lactation on the performance of lactating primiparous sows and nursing piglets. Journal of Animal Science, v.86, p. 827-835, 2008. Available from: <http://www.journalofanimalscience.org/ content/86/4/827.full.pdf + html $>$. Accessed: Jan. 12, 2010. doi: $10.2527 /$ jas. $2007-0371$.

NOBLET, J.; ETIENNE, M. Metabolic utilization of energy and maintenance requirements in lactating sows. Journal of Animal Science, v.64, p.774-781, 1987. Available from: <http://www. journalofanimalscience.org/content/64/3/774.full.pdf $>$. Accessed: Mar. 6, 2014.

NRC (NATIONAL RESEARCH COUNCIL). Nutrient requirements of swine. 11.ed. Washington, DC: National Academic, 2012. 242p.

O'QUINN, P.R. et al. Arginine catabolism in lactating porcine mammary tissue. Journal of Animal Science, v.80, p.467-474, 2002. Available from: <http://www.journalofanimalscience.org/ content/80/2/467>. Accessed: Feb. 16, 2012.

REYES, A.A. et al. Role of arginine in health and in renal disease. American Journal of Physiology: Renal Physiology, v.267, n.3, p.331-346, 1994
ROSTAGNO, H.S. et al. Tabelas brasileiras para aves e suínos: composição de alimentos e exigências nutricionais. Editor: Horácio Rostagno, 3.ed. Viçosa: UFV, DZO, 2011. 252p.

SAS. SAS/STAT ${ }^{\circledR}$ 9.3 User's guide. Cary, NC: SAS Institute, 2005. 8621 p.

TROTTIER, N.L. et al. Plasma amino acid uptake by the mammary gland of the lactating sow. Journal of Animal Science, v.75, p.1266-1278, 1997. Available from: <http:// www.journalofanimalscience.org/content/75/5/1266>. Accessed: Feb. 23, 2014.

WU, G.; MORRIS, S.M. Arginine metabolism: nitric oxide and beyond. Biochemical Journal, v.336, p.1-17, 1998. Available from: $<$ http://www. biochemj.org/bj/336/0001/3360001.pdf>. Accessed: May 3, 2010.

WU, G.; MEININGER, C.J. Arginine nutrition and cardiovascular function. Journal of Nutrition, v.130, p.2626-2629, 2000. Available from: <http://jn.nutrition.org/content/130/11/2626.full. pdf $>$. Accessed: Nov. 15, 2010.

WU et al. Arginine nutrition in development, health and disease. Current Opinion in Clinical Nutrition \& Metabolic Care, v.3, p.59-66, 2000

WU, G. et al. Arginine nutrition in neonatal pigs. Journal of Nutrition, v.134, p.2783S- 2790S, 2004. Available from: $<$ http://jn.nutrition.org/content/134/10/2783S.full.pdf $>$. Accessed: Nov. 15, 2010.

WU, G. et al. Pharmacokinetics and safety of arginine supplementation in animals. Journal of Nutrition, v.127, p.2342-2349, 2007. Available from: <http://jn.nutrition.org/ content/137/6/1673S.full.pdf>. Accessed: Nov.10, 2010.

WU, G. et al. Impacts of arginine nutrition on embryonic and fetal development in mammals. Amino Acids, v.45, p.241-256, 2013. Accessed: Jul. 9, 2013. doi: 10.1007/s00726-013-1515-z.

YANG, Y. et al. Effects of dietary energy and lysine intake during late gestation and lactation on blood metabolites, hormones, milk composition and reproductive performance in multiparous sows. Archives of Animal Nutrition, v.62, p.10-21, 2008. Accessed: Jul. 9, 2013. doi: 10.1080/17450390701780227.

YEN, J.T. et al. Difference in rates of net portal absorption between crystalline and protein-bound lysine and threonine in growing pigs fed once daily. Journal of Animal Science, v.82, p.1079-1090, 2004. Available from: <http://jas.fass.org/cgi/ content/full/82/4/1079>. Accessed: Oct. 15, 2010. 